Abstracta Iranicacta Iranica

Revue bibliographique pour le domaine irano-aryen

Volume 29 | 2008

Comptes rendus des publications de 2006

\title{
Čāleš-e miyān-e fārsī va 'arabì. Sade-hā-ye naHost. Tehrān, Našr-e Ney, 2006, 324 p., index.
}

\section{Pollet Samvelian}

\section{(2) OpenEdition}

12 Journals

\section{Édition électronique}

URL : http://journals.openedition.org/abstractairanica/24432

DOI : 10.4000/abstractairanica.24432

ISSN : 1961-960X

Éditeur :

CNRS (UMR 7528 Mondes iraniens et indiens), Éditions de l'IFRI

\section{Édition imprimée}

Date de publication : 15 mai 2008

ISSN : 0240-8910

\section{Référence électronique}

Pollet Samvelian, « Čāleš-e miyān-e fārsī va 'arabī. Sade-hā-ye nahost. Tehrān, Našr-e Ney, 2006, 324 p., index. », Abstracta Iranica [En ligne], Volume 29 | 2008, document 26, mis en ligne le 15 septembre 2008, consulté le 26 septembre 2020. URL : http://journals.openedition.org/abstractairanica/24432 ; DOI : https://doi.org/10.4000/abstractairanica.24432

Ce document a été généré automatiquement le 26 septembre 2020.

Tous droits réservés 


\title{
Čâleš-e miyān-e fārsī va 'arabì. Sade- hā-ye naHost. Tehrān, Našr-e Ney, 2006, 324 p., index.
}

\author{
Pollet Samvelian
}

1 Même si nous connaissons l'histoire des premiers siècles de la domination arabe en Iran dans ses grandes lignes, le déroulement précis de certains événements ou processus majeurs reste néanmoins entouré d'un brouillard épais. La façon dont le persan dari a vécu et survécu, de même que l'intercompréhension entre les Arabes et les habitants persanophones font partie de ces mystères. C'est par ce constat que l'A. commence son livre. En effet, les récits des conquêtes restent généralement silencieux sur la langue des négociations et des accords conclus entre vainqueurs et vaincus. Que sait-on des habitants 'bilingues', qui ont dû jouer un rôle crucial dans l'intercompréhension entre les deux communautés, et, question plus importante encore, qu'en est-il des deux langues qu'ils maîtrisaient? Si pour les Arabes, on peut postuler, sans prendre trop de risques, l'existence d'une langue 'commune', l'arabe, rendant possible l'intercompréhension entre les membres de la communauté en dépit de leur appartenance aux différentes tribus de variations dialectales, la situation de la communauté 'persanophone' est en revanche nettement moins claire. Quelle était la situation linguistique sous la domination arabe et quel fut le cheminement du persan pour accéder progressivement au statut de la langue officielle? Quelles conclusions peut-on tirer de cette aventure ? En quoi nous permet-elle de mieux appréhender les liens entre le persan et la construction de l'identité iranienne ? Voici quelques-unes des questions auxquelles l'A. tente d'apporter une réponse en s'appuyant sur de nombreux essais et récits historiques. Livre érudit et extrêmement bien documenté, cet ouvrage passionnant reste néanmoins accessible à tous ceux qui s'intéressent à 'l'aventure du persan'. Ce livre fera l'objet d'un compte-rendu plus détaillé dans un des prochains numéros de Studia Iranica. 
INDEX

Thèmes : 2.2. Langues vivantes et dialectes

\section{AUTEURS}

\section{POLLET SAMVELIAN}

Sorbonne Nouvelle-Paris III - Mondes iranien et indien - Paris 